CATHARSIS 9 (1) 2020

Halaman: 1-9

p-ISSN 2252-6900 I e-ISSN 2502-4531

UNNES

Catharsis: Journal of Arts Education

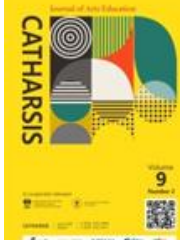

http://journal.unnes.ac.id/sju/index.php/chatarsis

\title{
The Form and Function of Antan Delapan Music in Muara Lawai Village, Muara Enim District
}

\author{
Aghnini Aghnini ${ }^{\bowtie}$, Sunarto Sunarto, Triyanto Triyanto \\ Email: aghnini89@gmail.com
}

Universitas Negeri Semarang, Indonesia

Received 26 December 201, Accepted 16 February 2020, Published 31 May 2020

\begin{abstract}
Abstrack
Antan Delapan music is one of the arts found in the district of Muara Enim, South Sumatra. Antan Delapan art is currently displaced by the development of western music, therefore the form and function of music plays an important role in maintaining the Antan Delapan music among the people of Muara Enim Regency. The purpose is to study the form and function of Antan Delapan music. The method in this study uses descriptive qualitative with an interdisciplinary approach, while the data collection technique uses observation, interviews, and document studies. The data validity technique uses source triangulation. Data analysis techniques use the concepts of Strauss and Corbic. The results of this study are the form of Antan Delapan music which is dissected through the elements of time, melody, harmony, while the function of Antan Delapan music in the community as, entertainment, aesthetic appreciation, means of communication, cultural harmony, and as an integration. And it is hoped that this research can be useful for the people of Muara Enim Regency, especially the Muare Lawai Village Community in order to know the function and form of Antan Delapan music and can maintain the Antan Delapan music among the Muare Lawai villagers, and is useful for readers who will use music theory about the form and music function.
\end{abstract}

Keywords: Antan Delapan, Form, Function

DOI : https://doi.org/10.15294/catharsis.v9i1.38242 


\section{INTRODUCTION}

Indonesia is a nation that has a variety of cultures. This ethnic diversity is a great wealth for the Indonesian people. Koentjaningrat (1990: 180) said: "culture is a whole system of ideas, actions, and results of human work in the context of community life that belongs to human self by learning". One product of culture is art. Art is one of the results of human creativity, taste, and intention which is manifested or stated in a work that has a beauty value. Art that is presented in society contains aesthetic expression activities that are classified into integrative needs, that is, needs arising from human impulses that essentially want to reflect their existence as moral, intelligent, and compassionate beings (Rohidi, 2000: 28).

Art grows and develops in Indonesia covering various branches of art, including visual arts, dance, music, theater or drama, and literary arts. One example of a highly developed art in Indonesia is the art of music. The art of music that grows and develops in the current era of modernization is a blend of ethnic music and Western music. With the current phase of modernization, the influence of Western music is growing rapidly compared to ethnic regional music, because Indonesian people have been accustomed to learning Western music from an early age. Therefore, Indonesian artists today combine a lot of ethnic music and western music, so that teenagers like ethnic music and can preserve it.

Muara Enim Regency is one of the regencies in South Sumatra Province. Muara Enim Regency has many traditional arts that have developed among the people of Muara Enim, among others, terbangan, rabana, saropal anam, antan delapan, tari sambut, kuda lumping, debus, and so forth.

Antan Delapan Art is a vocal group that is accompanied by musical instruments namely guitar, violin, bass, and drums which are played with feelings. Antan Delapan art was originally folklore of Muara Enim Regency which was appointed as an art that developed in the community of Muara Enim Regency. As in his story, according to Samsumar as chairman of the Antan music group, the Antan Delapan arts are songs to relieve the fatigue of farmers who are pounding rice using antan and dimples to relieve fatigue, so farmers pound rice while reciprocating rhyme or gurindam containing advice and values moral values contained in each of his softly. Whereas, mortar and antan become the accompaniment bar of reciprocating the rhymes of the farmers. But along with the development of the times of mortar and antan are no longer used and replaced with modern musical instruments such as drums and strikes as a rhythmic music instrument for the accompaniment, with the addition of melodic instruments such as violin, guitar, and bass.

Research on the form and function of Antan Delapan music in Muare Lawai village, Muara Enim Regency is one of the interesting objects to be studied, considering the existence of Antan Delapan art that is almost extinct is expected by the research conducted by researchers able to raise the existence of Antan Delapan art, so can be inherited and developed by the younger generation, so that the Antan Delapan art is not lost to the times. On the other hand, previous research related to the art of Antan Delapan only examines, social values in Antan Delapan art in the village of Penyandingan in Muara Enim district (Novita, 2014), studies conducted by previous studies provide different references and perspectives for researchers.

Based on explanations from the background and previous research, the researcher will analyze the form and function of the music Antan Delapan. This has attracted the interest of researchers to take this first title, namely: 1) there has been no research into the form of music Antan Delapan in depth; 2) Antan Delapan music in Muara Enim district has its characteristics, and 3) the next 
generation of Antan Delapan Music is rarely found (step).

\section{METHOD}

This research uses descriptive-analytic qualitative research methods with an interdisciplinary approach. The researcher used the musicology discipline Miller concept to study the form of music and Anthropology of the musical concept of Alan P. Merriam to study the function of music. While the focus of research in the form and function of Antan Delapan music in Muare Lawai village, Muara Enim Regency. Research data were collected using observation, interview, and document study techniques.

\section{RESULT AND DISCUSSION}

\section{Result}

\section{Observation}

Observations made include focusing on an object by using all the senses. Observations were made to obtain data regarding the form and function of Antan Delapan music directly during the performance.

Interview

This interview was addressed to Mr. Samsumar as Chairperson of the Deksangke Music Group to obtain information about the antan eight music functions, and the antan eight music players to obtain the antan eight music forms.

\section{Document Study}

Study documents obtained during the Antan Delapan music performance namely; 1) Video of the Antan Delapan art performance; 2) Antan Eight music recordings.

\section{Discussion}

The form of music is generally framed by a musical framework as well as a framework for living things so that its role is very large for a musical work. concerning "form" itself is defined as structure, articulation, a result of the overall unity of a relationship of various factors that cling together or rather a way in which all aspects can be linked (Langer, 1988: 16). Form of music is an idea or idea that appears in the management and arrangement of all elements of music in a composition that includes the rhythm, melody, and harmony of Harling (2017, p.58). According to Laycock \& Nordgren (2009, p.79), The form of music can also be said as a container that is filled by composers and processed so that it becomes living music. The musical instruments used in the Antan Delapan music are melodic and rhythmic, so the aspects of the Antan Delapan Music form are all made aware of the melodic and rhythmic buildings that are knitted by instruments and the term melodic issues in the Antan Delapan music play by the Muara Enim community is called the swing.

Antan Delapan in an explicit musical context also requires a comprehensive involvement for all players. The music also must heed the details of the singer's vocal sound. Seeing from the process is very possible to give effect to the sensitivity, order, and smoothness felt by the audience. The musical position has the authority to control the poem text that is played. This can be seen when the song text (poetry) adjusts to the song swing.

Judging from the language used, aspects of poetry in rhymes as material swings are also shaped by the influence of the Merinem dialect which is influenced by the natural surroundings. the dialect of language in Merinem's community always uses the suffix $/ / \mathrm{e} / /$ at the end of the word. Vocal issues in this context need to be examined first, which is based on the findings of field data. Furthermore, it was continued to explain the matter of musical sentences. as a description of the poem of Antan Delapan music, an example of the intended poem is given.

Antan Delapan

sayang pembarap rie ditebeng

Antan Delapan menutok diwek

Siape diharap siape disendeng 


\section{lain dibadan menyendeng diwek}

In the presentation, when the singer starts the vocal presentation. He must adjust to the violin game (as the main melody). this shows that the initial vocal swing formed is entirely constructed by the initial swing built by the violin.

\section{The elements of Antan Delapan Music}

Penjelasan tentang bentuk musik Antan Delapan pada grup musik Dek Sangke menggunakan konsep musikologi tidak terlepas dari unsur pembentuk musik yaitu elemen waktu, melodi, dan harmoni. Musik yang disajikan oleh kesenian Antan Delapan didasari oleh cerita kehidupan, kegalauan, kesedihan, dinyayikan menggunakan pantunpantun yang diiringi oleh alat musik melodis dan ritmis (biola, ritem, melodi, bass, tamborin, drum).

The elements in music described by researchers in the form of Antan Delapan art which are rhymes or gurindam are packaged into musical offerings that are pitched in general, and as a whole are repetitions/melodies and rhythmic repetitions of music which in music terms are called repetition. in the Antan Eight art which forms a musical unity consisting of three main elements namely, the elements of time, melody, and harmony which are described in the following research:

\section{Time Element}

According to Miller (in Sunarto, [ed.] 2017: 26), music is an art of the time; the medium is the actual sound (body), which does not remain but continues to move within a period. Therefore the elements of time are the foundation of music. Within the elements of music, there are three factors, namely tempo, meter, and rhythm. These factors are used by researchers in analyzing music in the art of Antan Delapan as follows:

\section{Tempo}

The term comes from Italian which means time. If used in music terms it shows fast or slow. According to Miller (in Sunarto, [ed.] 2017: 26), in music can be seen how fast, music can move at a very fast, medium, or slow speed and various levels between them. This is confirmed by Benward and Saker (2008: 26) who say that the tempo is the speed of the rhythm in music, which can be stated in general or in a beat per minute. So from the two statements and the results of a documentation study in the form of a musical notation transcript based on the video performance of Antan Delapan, it can be seen in the song Antan Delapan that the tempo or speed used is meno mosso, which means slower, which is based on the speed of the rhythm of Antan Delapan music on drum and tambourine instruments, and which became the initial benchmark for entering music is the initial melody or played by violin.

\section{Meter}

The term comes from Italian which means time. If used in music terms it shows fast or slow. According to Miller (in Sunarto, [ed.] 2017: 26), in music can be seen how fast, music can move at a very fast, medium, or slow speed and various levels between them. This is confirmed by Benward and Saker (2008: 26) who say that the tempo is the speed of the rhythm in music, which can be stated in general or in a beat per minute. So from the two statements and the results of a documentation study in the form of a musical notation transcript based on the video performance of Antan Delapan, it can be seen in the song Antan Delapan that the tempo or speed used is meno mosso, which means slower, which is based on the speed of the rhythm of Antan Delapan music on drum and tambourine instruments, and which became the initial benchmark for entering music is the initial melody or played by violin. 
Signals indicated by drawing vertical lines on the staves. In most music, there is an equal number of beats for each bar. So based on the results of research observations on the art of Antan Delapan it can be seen that the meter or sukat used is $4 / 4$, meaning that there are fourquarter notes of each beat. 4/4 sukat sign in the art of Antan Delapan can be seen in the following picture:

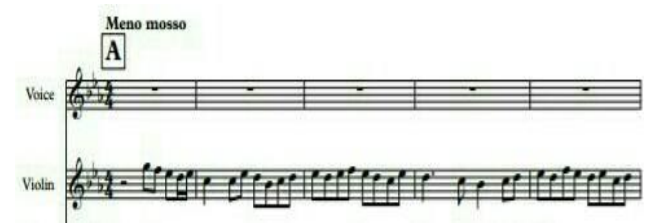

Figure 1. Notasi musik antan Delapan (Transkip: Aghnini,2019)

\section{Rhythm}

Rhythm is a sequence of motion sequences that forms a basic element in music and dance. Rhythm in music is formed from a group of sounds and still signs with various lengths of time or the length of the short songs that form rhythm patterns and move according to Jamalus swing bar (1988, pp. 7-8). According to Miller (in Sunarto, 2017, p.28), rhythm is one of the most difficult musical concepts to define. There are various definitions for this term, but in order to achieve certain goals, it can assume the rhythm as a time element in music produced by two factors, namely: (1) accent, namely the pressure or emphasis on a note to make it sound louder. The accent can correspond to the metric pattern that is placed on the first beat of each bar, (2) The short length of a note or duration, as already mentioned, the tones of different durations produce a rhythm, namely: the choice of notes long and short.

The rhythm of the Antan Delapan music has one type of rhythmic pattern that is repeated in each of his music games. Figure 2 shows the rhythm or beat notation in the playing of drum and tambourine in the Antan Delapan music.

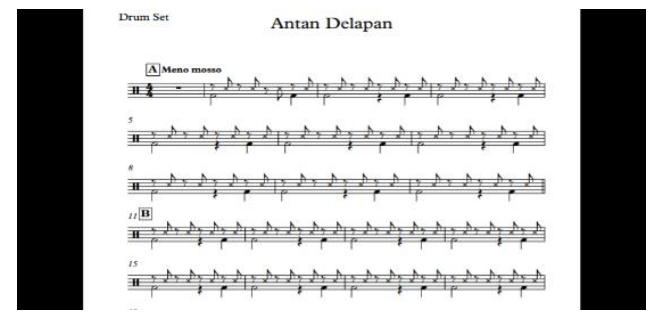

Figure 2. The rhythm notation of the drum set music Antan Delapan

(Trancript: Aghnini,2019)
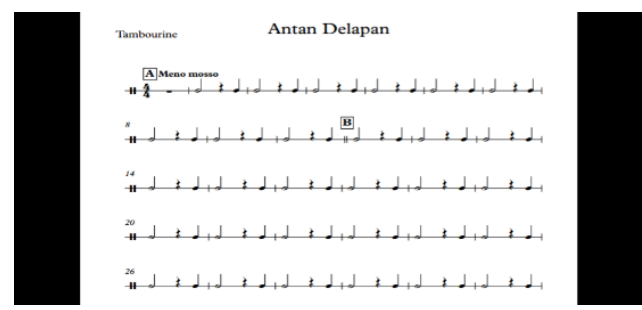

Figure 3. Rhythmic tambourine notation of antan delapan music

(Transcript: Aghnini, 2019)

Seen from the two types of musical instruments used in the Antan Delapan music game, shows the different rhythmic patterns of each rhythm. The first rhythm pattern on the drum drum set uses the note value of 2 beats. It starts with a beat of $1,2 \frac{1}{2}, 3 \frac{1}{2}$ which each beat beats dug no, no, no, dup no, and is played on each repeatedly bar, while The tambourine instrument hits the note value of 2 beats, which is hit on the first bar, knocked to 1 , and to 4 that every beat sounds and is played on each bar repeatedly.

\section{Melody}

Melody is the basis for musical compositions, musical melodies are created musical ideas (Pier in Hanifa, 2019, p. 288). A melody is an arrangement of tones (sounds with regular vibrations) that sound sequentially and in time and use a Jamalus idea (1988, p.16). Meanwhile, according to Reed and Sidnell (1978: 104) that a melody can be considered as a sequence of regular and horizontal tones that are heard as dominating lines. so from the three statements and related to the results of the 
documentation study in the form of transcript notation, it can be seen that the melody in the Art of the Antan Delapan can be seen from the vocal sounds and main melodies played by violin instruments that have high and low, short lengths of regular and horizontal notes. Figure 4 shows the existing vocal melodies in the Antan Delapan music played using the $3 \mathrm{~b}$ (3 mol) or Do $=$ Eb scales.

It can be seen that the vocal melodies in the Antan Delapan music which when viewed from the length of the short tone more often use half-beat notes, and at least use 2 beat notes, while from the high and low notes, the highest note is the C (la) note, and the lowest note is toneF(re).
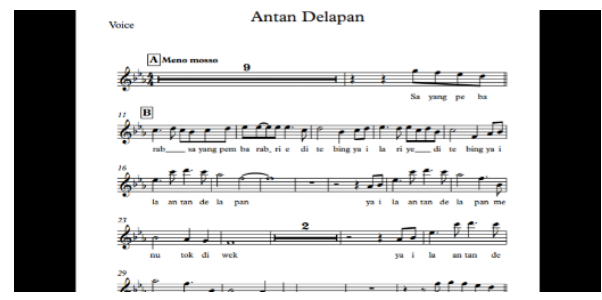

Figure 4. Antan Delapan music voice melody notation

(Transcript: Aghnini, 2019).

\section{Harmony}

Harmony is the arrangement of a series of chords so that the music can be heard and harmonious. According to Syariq (in Soemanang 2013, p.28) harmony is a matter of harmony of the chorus. Harmony technically includes the composition, role, and relationship of a chorus with each other, or with the whole form. Harmony is a combination of chords, namely concepts and functions and their relationship with each other.

The music played by the artist Antan Delapan always pays attention to parts of the musical elements called harmony. The element of harmony is carried out so that there is a match between rhythm or rhythm and melody. The element of harmony includes the use of various kinds of chords along with the progression of the displacement of the composition, the harmonious merging of tones will form harmonious music as well. The following are some examples of chord changes played on Antan Delapan music. The chord transfer in song $A$ is $\mathrm{Fm}|\mathrm{Eb}| \mathrm{Bb}|\mathrm{Eb}| \mathrm{Ab}|\mathrm{Eb}| \mathrm{Fm}$, while the chord transfer in song $\mathrm{B}, \mathrm{Eb}$ $\mathrm{Bb}|\mathrm{Eb}| \mathrm{Ab}|\mathrm{Eb}| \mathrm{Fm}|\mathrm{Ab}| \mathrm{Eb}$.

\section{The Function of Antan Delapan Art}

The function of art is related to the life of the surrounding community. According to P. Merriam (1964, p. 218), the function of an element of culture in society is the effect of benefits (effectiveness) in meeting the needs or in achieving certain goals. In its contribution to community life, Antan Delapan art has a variety of functions based on the purpose of its presentation as follows.

\section{The Function of Antan Delapan Art as Entertainment}

Merriam (in Indriani, 2016, p.10) music has an entertainment function referring to the understanding that music must contain entertaining elements. This can be judged by the melody and the lyrics.

Based on the observations of researchers, the Antan Delapan music entertainment program at the time of the excellent performance or singer must be good at speaking in singing songs that will be sung. In addition, being good at poetry, the belle is required to be clever in finding a partner to be invited to sing or reciprocate on stage. With the excellent primadonna inviting couples and unrequited rhyme on the stage that makes the other audience entertained by the excellent looking for their partner.

Antan Delapan music usually serves to entertain at weddings, circumcisions, the commemoration of village anniversaries, national holidays such as August 17, Muara Enim regency anniversary in accordance with the function stated by Alan. P. Merriam. 
The Function of Antan Delapan Art as Aesthetic Appreciation.

Merriam (in Rismawan, 2014, p.5) revealed that music is a work of art. Something can be said as a work of art if it has an element of beauty or aesthetics in it. Mustikasari (2013, p.25). Through music, we can get to know the values of beauty through melody or dynamics.

Based on the researchers' observations, it can be seen that when the music of Antan Eight is performed, the guests who are around the location of the show will spontaneously see and listen to the Antan Eight music playing by artists and eight musicians who sing poems or pantindam or gurindam. The audience is guests or people from other villages who love the antan Delapan music, guests or people from other villages who want to enjoy the Antan Delapan music are children, adolescents, and adults. So everyone can enjoy the Antan Delapan music performance and the audience can enjoy every rhythm and melody played by the artists Antan eight.

From the above statement, it can be concluded that the Antan Delapan music, especially the poems of rhyme or gurindam that is performed serves as an aesthetic appreciation for guests and connoisseurs of Antan Delapan music. The prima donnas or singers who sing different verses and each chanted song have different rhythms, melodies, and harmonies. So, the audiences enjoy the performance of the Antan Delapan music respectfull.

\section{The Function of Antan Delapan Art as a Means of Communication}

Music has a communication function that means that applicable music contains its cues that are only known by the community supporting culture. This can be seen from the text or melody of the music being played. Meanwhile, according to Lorimer (in Dalori, 2019 p.338) he states that generally, the communication function shows the flow of movements that go hand in hand with society or individuals.

Based on the observations of researchers in the field, songs sung in the art of Antan Delapan, recited poems tell about life and convey the messages contained in poetry or rhymes spoken. Usually the contents of rhymes or gurindam spoken according to adjust the program. If at a wedding, the rhymes that are delivered contain messages for the bride and groom. Although the context of this communication may not necessarily be interpreted by all audiences or connoisseurs of art among the eight, at least there has been a communication treatment, in which music has become a medium of communication.

\section{The Function of Antan Delapan Art as Cultual Sustainability}

This function is almost the same as the function relating to social norms. In this case, the music contains the teachings to continue the cultural system of the next generation.

Based on the observations of researchers, Antan Delapan art is a tradition that has existed since ancient times which continues to be preserved until now. This can be proven at a wedding in Muara Enim Regency which still uses the Antan Delapan art as a means of entertainment for guests and hosts. Antan Delapan arts are taught from generation to generation by artists and parents to the surrounding community and their children. Because this art must be taught and studied by young people because Antan Delapan art is a cultural identity. Therefore this art must continue to be passed on and preserved to subsequent generations.

\section{The Function of Antan Delapan Art as Social Integration}

Social integration is a process of maintaining the survival of groups that will never be finished continuously (Ikra in Elu, 2019, p.163). Music has social integration in society. If the music played together then the 
music unwittingly creates a sense of togetherness between music artists.

Based on the observations of researchers, Antan Delapan Art which is played together creates cohesiveness between fellow artists. This can be seen from the rhymes between primadonna or choir of one other midwifery, while between the music player and the belle or singer so that poetry and melody can be in harmony. The cohesiveness of the music players not only at the time of appearance, but the cohesiveness is also intertwined in everyday life as well

\section{CONCLUSSION}

Based on the results and discussion of the research that has been presented previously, it can be concluded that the form of Antan Delapan music consists of three elements, namely the elements of time, melody, and harmony. The time element has three elements contained in it namely, tempo, meter, and rhythm. Tempo used is meno mosso which means slower (slower), the meter uses $4 / 4$ sukat, meaning there are four quarter notes in one bar, and the rhythm pattern is divided into two rhythms because it uses two instruments and has different rhythms, at many drum set instruments use the note $1 / 2$ beat and cover, while the tambourine instrument uses note 2 beat where each instrument uses a rhythm that is repeated over and over again in the next bar. Melodies generally use more half-tap notes with the basic note Do $=3 \mathrm{~b}$ (three moles) or Do $=\mathrm{Eb}$, the high note used $\mathrm{C}$ (la) and the low note used, F (re). The harmony used consists of song A and Song B, Song A is the chord transfer, $\mathrm{Fm}|\mathrm{Eb}| \mathrm{Bb}|\mathrm{Eb}| \mathrm{Ab}|\mathrm{Eb}| \mathrm{Fm}$, while the chord transfer in song $\mathrm{B}, \mathrm{Eb}$ $\mathrm{Bb}|\mathrm{Eb}| \mathrm{Ab}|\mathrm{Eb}| \mathrm{Fm}|\mathrm{Ab}| \mathrm{Eb}$.

The function of Antan Delapan music in the community in Muara Enim Regency is as entertainment that is, entertainment for connoisseurs and spectators, as aesthetic appreciation, ie the audience is able to enjoy and feel the beauty of the melody being played, as communication in which music as a means of communication to convey moral messages is contained in poetry, as the continuity of culture that is, the art of Antan Delapan taught from generation to generation of generations so that the Antan Delapan art is not extinct in the shift of times, and as an integration of society, namely creating a relationship of togetherness and harmony for artists.

\section{SUGGESTION}

Thanks to the superiors who have mobilized and directed the writing in completing scientific papers in this research. Based on the results of research that has been done, it is better if the researcher gives advice to the people of Muara Enim district to continue to maintain, develop, pass down, and preserve traditional arts that have existed, so that they can continue to exist until the next generation because in the Antan Delapan text there are values the values and teachings of doing good that can be applied in everyday life.

Suggestions for the Muara Enim City government to continue to preserve and preserve local cultural assets in the form of traditional arts that already exist. As well as providing a place or place for performances and arts. Appreciation to artists in Muara Enim Regency to continue to be eager to develop and introduce Antan Delapan Art to all Indonesian people.

\section{REFERENCES}

Benward, Bruce \& Saker,Marilyn. 2008. Music in Theory And Practice (English Edition-Volume I) New York: McGrawHill.

Dolari, Sumaryanto Totok, Utomo Udi. 2019. " The Process And Function Opf Rebana Music Gendukan Jawan As A Communication Of Kelompok Informasi Masyarakat (KIM). Jurnal 
Catharsis : Journal of Art Education, Vol 8 (3).

Elu, A R Agustinus, Utomo, Udi, Sunarto. 2019."The Fungsion of The Timorese Gong Music In The Tfua Ton Ritual Ceremony in Napan Kefamenanu Village". Jurnal Catharsis : Journal of Art Education, Vol 8 (2).

Hanifa, Sumaryanto, totok, Wadiyo,f. 2019. "Gambus Al-Mubarok's Studio : Form and Structure of Music". Jurnal Catharsis : Journal of Art Education, Vol 8 (3).

Harwanto, Candra Dody. (2018). " Bentuk dan Struktur Kesenian Kentrung di Jepara". Jurnal Resital, Vol.19 no.01.

Indriani,Fittiana. 2016. " Fungsi dan UnsurUnsur Musik Madihin di Kecamatan Tembilahan Kabupaten Indragiri Hilir". Jurnal KOBA, Vol 3, No2, 1-13

Jamalus. 1988. “ Musik dan Praktek Perkembangan Buku sekolah Pendidikan Guru". Jakarta : CV.Titik Terang.
Koentjaraningrat. 1990. “ Pengantar Ilmu Antropologi”. Jakarta : PT Rineka Cipta.

Laycock R. Harold \& Quentin R,Nordgen. 2009. "Music Theory. Ace. Bringnam New York : Young University.

Merriam, Alan P. 1964. " The Antropology Of Music. Chicago : Northwestern University Press.

Miller, Hugh M.(2017)." Apresiasi Musik". Sunarto (Ed). Yogyakarta: Tafa Media.

Reed, H O \& Sidnell, R G. (1978). "The Materials Of Music. Composition" ( Book I : Funda Mentals). America Addision : Wesley Publising Company.

Rismawan, A Septian. (2014). " Ekspresi Musikal dan Fungsi Musik Saestu Band Reggae Bagi Masyarakat Kota Semarang. Jurnal Catharsis Journal of Art Education, Vol 3 (1).

Rohidi, Tjetjep Rohendi. 2000. "Kesenian Dalam eEndekatan Kebudayaan”. Bandung : STSI Press

Rohidi, Tjetjep Rohendi. 2000. " Metode PEnelitian Seni”. Semarang : Cipta Prima. 